\title{
Öğretmen Yetiştiren Programlara Kayıtlı Öğrencilerin Öğretmenlik Mesleğine Yönelik Tutumları ve Öğretmen Öz-Yeterlik Algıları
}

\author{
Attitudes toward Teaching Profession and Teacher Self-Efficacy \\ Beliefs of Students in Teacher Training Programs \\ Levent YAKAR*, İsmail YELPAZE \\ - Geliş Tarihi: 23.10.2018 • Kabul Tarihi: 01.04.2019• Yayın Tarihi: 06.07.2019
}

\section{$\ddot{\mathbf{O z}}$}

$\mathrm{Bu}$ araştırmada öğretmen yetiştiren farklı programlara kayıtlı öğrencilerin öğretmenlik mesleğine yönelik tutumları ve öğretmen öz-yeterlik algılarının incelenmesi amaçlanmıştır. Bu araştırma ile öğretmen yetiştirme misyonuna sahip tüm fakülte ve program türlerindeki öğrencilerin öğretmenlik mesleğine yönelik tutumları ve öğretmen öz-yeterlik algılarının ilk kez karşılaştırılması çalışmanın önemini ortaya koymaktadır. Araştırmanın örneklemini bir devlet üniversitesinin eğitim fakültesi, ilahiyat fakültesi, beden eğitimi ve spor yüksekokulu (BESYO), fen- edebiyat fakültesi ve pedagojik formasyon eğitimi programlarında öğrenim gören 786 öğretmen adayı oluşturmaktadır. Veri toplamada Çetin (2006) tarafından geliştirilen öğretmenlik mesleğine yönelik tutum ve Baloğlu ve Karadağ (2008) tarafından Türkçeye uyarlanan öğretmen öz-yeterlik ölçekleri kullanılmıştır. Yapılan analizler sonucu öğretmenlik mesleğine yönelik tutumda BESYO'da, öğretmen öz-yeterlik algısında ise ilahiyat fakültesinde öğrenim gören öğretmen adaylarının diğer tüm birimlerdeki öğretmen adaylarından anlamlı olarak daha düşük düzeye sahip oldukları görülmüştür. Ayrıca öğretmen adaylarının mesleğe yönelik tutumları ve mesleki yeterlilik algıları çeşitli demografik değişkenler açısından karşılaştırılmış ve sonuçlar literatürdeki sonuçlarla birlikte tartışılmıştır.

Anahtar sözcükler: öğretmenlik mesleğine yönelik tutum, öğretmen öz-yeterlik algısı, öğretmen aday1, öğretmen yetiştiren programlar

Atıf:

Yakar, L., ve Yelpaze, İ. (2019). Öğretmen yetiştiren programlara kayıtlı öğrencilerin öğretmenlik mesleğine yönelik tutumları ve öğretmen öz-yeterlik algıları. Pamukkale Üniversitesi Eğitim Fakültesi Dergisi, 47, 107-129. doi: 10.9779/pauefd.473678

\footnotetext{
* Dr. Öğr. Üyesi, Kahramanmaraş Sütçü İmam Üni. Eğitim F. Eğitim Bil. Böl., 1 yakar@hotmail.com, https://orcid.org/0000-0001-7856-6926

Dr. Öğr. Üyesi, Kahramanmaraş Sütçü İmam Üni. Eğitim F. Eğitim Bil. Böl., ismailyelpaze@gmail.com, https://orcid.org/0000-0003-4428-0502
} 


\begin{abstract}
In this study, it was aimed to examine of the attitudes towards teaching profession and teacher self-efficacy beliefs of students in different teacher training programs. The first time comparison of students' self-efficacy perceptions and attitudes towards teaching profession in all faculty / program types with teacher training mission, it is emphasizes of importance of this study. 786 preservice teachers at faculty of education, faculty of theology, school of physical education and sports, faculty of science and letters and pedagogical formation education in a public university in Turkey, joined the study. The attitude towards teaching profession scale, developed by Çetin (2006) and teacher selfefficacy beliefs scale, adapted to Turkish Baloğlu and Karadağ (2008), were used. According to result of analyzes, it was seen that preservice teacher who were studying in the school of physical education and sports have lower attitude towards teaching profession score than all other units' students, significantly. Similarly, students of faculty of theology have lower teaching self-efficacy belief score than other units' students, significantly. In addition, the attitudes of preservice teachers towards the profession and beliefs of teacher self-efficacy beliefs were compared in terms of various variables. The results were discussed in the light of results in the literature.
\end{abstract}

Keywords: attitudes toward teaching profession, teacher self-efficacy beliefs, pre-service teacher, teacher training units

\title{
Cited:
}

Yakar, L., \& Yelpaze, İ. (2019). Attitudes toward teaching profession and teacher self-efficacy beliefs of students in teacher training programs. Pamukkale Üniversitesi Eğitim Fakültesi Dergisi, 47, 107-129. doi: 10.9779/pauefd.473678 


\section{Giriş}

Eğitim sistemi okul, yönetici, öğrenci, veli, öğretmen gibi pek çok unsurdan oluşmaktadır. Eğitim sisteminde bulunan faktörlerden öğretmenlerin bu sistemin temel öğesi olduğu ve diğer öğeleri etkileme gücü bulunduğu belirtilmektedir (Çapa ve Çil, 2000; Demirtaş, Cömert ve Özer, 2011). Öğretmenlerin niteliğindeki artışın sistemdeki diğer unsurlara ve sistemin geneli üzerinde olumlu etkileri olacağı söylenebilir. $\mathrm{Bu}$ nedenle eğitim sisteminin başarısının sağlanması için nitelikli öğretmen yetiştirmek öncelikli ve önemli konuların başında gelmektedir.

"İyi öğretmenin sahip olması gereken nitelikler nelerdir?" sorusuna verilebilecek pek çok yanıt olabilir. Öğretmen sadece mesleki bilgi ve becerilerini sergileyen değil aynı zamanda ortaya koyduğu tutum ve değerlerle de öğrencilerine model olan kişidir (Milli Eğitim Bakanlığı, 2017). Öğretmenin kendi mesleğine karşı olumlu tutum beslemesi ve yaptığ1 görevde kendisinin yeterli olduğuna inanması temelde iki önemli özellik olarak görülebilir. Nitekim bu iki özelliğin öğretmenin düşünsel süreçlerini, sınıf uygulamalarını, değişimini ve öğretmeyi öğrenmesi açısından önemli yapılar olduğu belirtilmektedir (Richardson, 1996; Rimm-Kaufman ve Sawyer, 2004). Öğretmenlerin istenen bu niteliklere ne kadar sahip olduğuna ilişkin bulgular, onların ne derecede iyi bir öğretmen olduğu/olacağına ilişkin de bir ipucu teşkil edecektir.

\section{Öğretmenlik Öz-yeterlik İnancı}

Öz-yeterlik inancı alanyazına sosyal-bilişsel öğrenme kuramının savunucusu Albert Bandura tarafından kazandırılmıştır. Öz-yeterlik, kişinin bir işi yapabilmek için gerekli olan işleri organize edip, kendisinin bu işte başarılı olma kapasitesine ilişkin algısı olarak ifade edilmektedir (Bandura, 1997). Buna göre, herhangi bir konuda gerekli yeteneğe sahip olduğuna inanan kişi bu yeteneğe sahip olmasa dahi olumlu bir öz-yeterlik duygusu geliştirebilir. Benzer şekilde kişi yeteneğe sahip olduğu halde olumsuz bir öz-yeterlik duygusu beslerse sahip olduğu yeteneği etkili bir şekilde kullanamayabilir (Bandura, 1977, Akt: Baloğlu ve Karadağ, 2008). Buna göre öz-yeterlik algısı bir yeteneğin varlığından ziyade, bireyi harekete geçirici, motive edici bir düşünce gücü olarak görülebilir.

Öğretmen öz-yeterliği ise, öğrencilerin başarısını ve öğrenmelerini sağlayacak yeteneğe sahip olduklarına ilişkin öğretmen yargılarıdır (Armor vd., 1976, Bandura, 1977, Akt: Tschannen-Moran ve Woolfolk-Hoy, 2001). Buna göre bir öğretmen adayının da mesleğine başladığında bu meslekte ne kadar başarılı olacağına yönelik algısı onun öz-yeterlik inancını oluşturur (İpek ve Demirel, 2012). Mesleğe yeni başlayacak olan öğretmen adayları doğal olarak çeşitli kaygılar yaşarlar. Bu kaygı durumu da bireyin benliğini tehdit edici olabilir (Cüceloğlu, 2006). Bu durumda öz-yeterlik algısı, kaygıyla başa çıkmada etkili bir faktör olarak devreye girebilir. Ayrıca mesleki öz-yeterlik algısı yüksek olan öğretmenlerin sorunları çözmek için daha fazla mücadele ettikleri, bireysel farklılıklara daha dikkat ettikleri, öğrenmede güçlük çeken öğrencilerden vazgeçmeden onlarla daha fazla ilgilendikleri ve destekleyici oldukları belirtilmektedir (Tschannen-Moran, Woolfok Hoy ve Hoy, 1998). Bu bağlamda öz-yeterlik inancının öğretmenlerin mesleki davranışlarında da etkin bir faktör olduğu görülmektedir. 


\section{Öğretmenlik Mesleğine Yönelik Tutum}

Tutum, bir olaya, duruma veya nesneye yönelik bireyin hoşlanma-hoşlanmama eğilimi (Kenrick, Neuberg ve Cialdini, 2005) veya bireyin bir objeye yönelik duygu-düşüncedavranışsal eğilimleri olarak tanımlanmaktadır (Kağıtçıbaşı, 2013). Bireylerin yaptıkları işe, mesleklerine yönelik tutumları meslekteki başarı ve mesleki doyumlarını etkileyebilecek önemli bir faktör olabilir. Nitekim öğretmenlerin mesleklerine ilişkin tutumlarının onların mesleki davranışlarını yönlendirmede oldukça belirleyici olduğu (Özkan, 2012), olumlu tutumun meslekte başarıyı ve doyumu sağladığı belirtilmektedir (Recepoğlu, 2013). Tutumlar bireyin göstereceği davranışlarda belirleyici olduğundan, öğretmen adaylarının mesleğe yönelik tutumlarının da, öğretmenlik mesleğine başladıklarında gösterecekleri performansa ilişkin öngörüde bulunabilmek için bir bilgi sunacağı açıtır (Üstüner, 2006).

Öğretmen adaylarının öz-yeterlik algılarının ve mesleğe karşı olan tutumlarının öğretmenlik mesleğini başarıyla yerine getirmede önemli etkilerinin olduğu görülmüştür (Demirtaş, Cömert ve Özer, 2011). Bu iki özelliğin birbiri üzerinde de etkili olduğu söylenebilir. Mesleğine ilişkin olumlu tutuma sahip olmayan bir öğretmenin kendini meslekte geliştirmeye adamayacağı ve kendini yeterli görmeyeceği söylenebilir. Benzer şekilde kendinin mesleğin gerekliliklerine sahip olmadığını düşünen bir öğretmen mesleğine karşı olumsuz tutumlar geliştirebilir. Bu bağlamda nitelikli öğretmen yetiştirilmesi için öğretmen adaylarına mesleğe ilişkin öz-yeterlik inancı ve olumlu tutumun kazandırılmasının önemli olduğu söylenebilir.

Öğretmen yetiştirme konusunda üniversitelerin eğitim fakülteleri etkin bir rol üstlenmiştir. Ancak çeşitli nedenlerle farklı fakülteler (İlahiyat, Beden Eğitimi ve Spor Yüksek Okulu -BESYO) ve formasyon eğitimi (Fen Edebiyat öğrencilerine ve farklı fakülte mezunlarına yönelik) gibi farklı sertifika programları ile de öğretmen adayları yetiştirilmektedir. Öğretmen yetiştirme programlarının çeşitlenmesi ile birlikte, bu fakülte ve programlardaki öğretmen adaylarının, öğretmenlerin sahip olması gereken nitelikleri ne ölçüde kazandıkları araştırmalara konu olmuştur (Yüksel, 2004). Bununla beraber öğretmen yetiştirme programlarında farklı seçme yöntemleri kullanıldığı için, bu alanları tercih eden ve mezun olacak olan öğretmen adaylarının kendilerini ne kadar yeterli hissettikleri ve yapmayı düşündükleri öğretmenlik mesleğine yönelik tutumlarının nasıl olduğu da araştırmacıların dikkatini çekmiştir.

\section{Amaç}

Bu çalışmanın amacı Eğitim Fakültesi (EF), İlahiyat Fakültesi (IF), Beden Eğitimi ve Spor Yüksek Okulu (BESYO), Fen-Edebiyat Fakültesi (FEF) ve Pedagojik Formasyon Eğitimi (PFE) programlarına devam etmekte olan öğretmen adaylarının öz-yeterlik inançları ve öğretmenlik mesleğine yönelik tutumlarını karşılaştırmaktır. Bu temel amaç doğrultusunda aşağıdaki alt amaçlara ilişkin analizler gerçekleştirilmiştir.

\section{Araştırmanın alt amaçları}

(1) Öğretmen adaylarının öğretmen öz-yeterlik algıları ile öğretmenlik mesleğine yönelik tutumları arasında ilişki düzeyini tespit etmek ve (2) kayıtlı oldukları program, (3) yaş, (4) cinsiyet, (5) medeni durum, (6) öğretmenlik mesleğini önceleme, (7) öğrenim durumu, (8) çalışma durumu, (9) gelir düzeyi değişkenleri açısından karşılaştırmaktır. 


\section{Araştırmanın Önemi}

Öğretmenlik mesleğine yönelik tutum ve öğretmen öz-yeterliliği konusunda çok sayıda çalışma yapıldığı görülmektedir. Bu çalışmaların çoğu, eğitim fakültesi öğrencileri (Bümen ve Özaydın, 2013; Serin, Güneş ve Değirmenci, 2015), pedagojik formasyon öğrencileri (Adıgüzel, 2017; Can, 2017; Güngör ve Özdemir, 2017), öğretmenler (Ünsal, Korkmaz ve Perçin, 2016; Cebeci Emre ve Ünsal, 2017), ilahiyat fakültesi öğrencileri (Kaya, 2003), BESYO öğrencileri (Abbasoğlu ve Öncü, 2013) ve tezsiz yüksek lisans öğrencileri (Yüksel, 2004) gibi tek grubun özelliklerini inceleyen araştırmalardan oluşmaktadır.

Farklı öğretmen kaynağında öğrenim gören öğrencilerin öğretmenlik mesleğine yönelik tutum veya öğretmen öz-yeterlik düzeylerinin karşılaştırıldığı çalışmalar da bulunmaktadır. Çalışmalara bakıldığında daha çok tezsiz yüksek lisans öğrencileri (Gürbüz ve Kışoğlu, 2007) veya formasyon öğrencileri (Ömür ve Nartgün, 2013; Poyraz ve Çağırgan Gülten, 2014; Dadandı, Kalyon ve Yazıcı, 2016) ile eğitim fakültesi öğrencilerinin karşılaştırılmasına odaklanıldığı dikkati çekmektedir. Bu çalışmada ise öğretmen yetiştiren tüm programlardan öğrencilere ulaşılmıştır. Bu sayede öğretmen adaylarının mesleğe ilişkin tutumları ve öz-yeterlik algıları öğretmen yetiştiren tüm birimler açısından incelenmiş ve karşılaştırılabilmiştir. Ayrıca araştırmalardaki karşılaştırmalardan sadece biri (Dadandı, Kalyon ve Yazıc1, 2016) öğretmenlik mesleğine yönelik tutum ve öğretmen öz-yeterliği birlikte incelemiş diğer çalışmalar ise bu özelliklerden sadece birine odaklanmıştır. Bu çalışma ile birbiriyle ilişkili olan bu iki özellik detaylı olarak birlikte incelenebilmiştir. Bunun yanında öğretmen adaylarının mesleki özyeterlik inançlarının ve mesleğe yönelik tutumlarının, mesleğe başladıklarındaki performanslarının bir göstergesi olacağı göz önünde bulundurulduğunda, araştırma sonuçlarının öğretmen yetiştirme sistemimizin niteliği konusunda yapılacak değerlendirmelere katk1 sağlaması beklenmektedir.

\section{Yöntem}

Bu çalışmada öğretmen adaylarının öğretmenlik mesleğine yönelik tutumları ve öğretmen özyeterlik algılarının farklı açılardan karşılaştırılması amaçlanmaktadır. Bu amaç doğrultusunda nicel araştırma yöntemlerinden ilişkisel tarama modeli araştırma deseni olarak tercih edilmiştir.

\section{Evren ve Örneklem}

Araştırmanın çalışma grubu 2017-2018 eğitim öğretim yılında, bir devlet üniversitesinde pedagojik formasyon derslerini alan EF, İF, BESYO, FEF ve PFE öğrencilerinden oluşmaktadır. Örneklemi oluşturan lisans öğrencilerinin öğretmenliği tanımaları adına 3. veya 4. sınıfta öğrenim görmelerine özen gösterilmiştir. Araştırma evreni toplam 2068 öğrenciden oluşmaktadır. Evreni oluşturan gruplardan BESYO ve EF'e kayıtlı öğrenci sayılarının azlığı nedeniyle bu gruplarda evrenin tamamına ulaşılmak istenmiştir. Diğer gruplarda uygun örnekleme yöntemi ile seçilen sınıflardaki öğrenciler örneklemi oluşturmuştur. Toplamda 824 öğrenci uygulamaya katılmış, 38 öğrenci maddelerin \%5'inden fazlasına yanıt vermemesi, tek veya çok değişkenli uç değer olmasından dolayı analize dâhil edilmemiş, 786 öğrenci yanıtı analize alınmıştır. Bazı demografik özelliklerini belirtmeyen öğrenciler sebebiyle analizlerdeki katılımcı sayıları farklılık gösterebilmektedir. Bağımsız değişkenlere ilişkin frekanslar Tablo 1 'de sunulmuştur. 
Tablo 1. Katılımcıların Demografik Özelliklerine İlişkin Dağılımı

\begin{tabular}{llllll}
\hline Değişken & & $\mathrm{f}$ & Değişken & & $\mathrm{f}$ \\
\hline Program & EF & 162 & Önceleme & Evet & 610 \\
& IF & 136 & & Hayır & 161 \\
& BESYO & 87 & & & \\
& FEF & 212 & Çalışma & Çalışmıyor & 608 \\
& PFE & 189 & & İşçi & 22 \\
& & & & D.Memur & 37 \\
Yaş & $\leq 20$ & 51 & & Ücr.Öğrt & 15 \\
& $21-25$ & 600 & & Diğer & 93 \\
& $26-30$ & 58 & & & \\
& $31-35$ & 47 & Öğrenim Durumu & Lisans Öğr. & 619 \\
& $\geq 36$ & 29 & & Lisans Mzn. & 139 \\
& & & & L.Üstü Öğr. & 19 \\
Cinsiyet & Kadın & 527 & & L.Üstü Mzn. & 8 \\
& Erkek & 255 & & & \\
& & & Gelir Düzeyi & $\leq 500$ & 427 \\
Medeni Durum & Evli & 105 & & $501-1001$ & 120 \\
& Bekâr & 671 & & $1001-1700$ & 42 \\
& & & & $1701-2500$ & 29 \\
& & & & $\geq 2500$ & 58 \\
\hline
\end{tabular}

\section{Veri Toplama Araçları}

\section{Kişisel bilgi formu}

Araştırmacılar tarafından geliştirilen ve araştırmanın ana değişkenlerinden olan öğretmenlik mesleğine yönelik tutum ve öz-yeterlik inançları ile ilişkili olabileceği literatür taramaları ile ön görülen demografik bilgilerin elde edilmesi amacıyla oluşturulan soruları içermektedir.

\section{Öğretmenlik mesleğine yönelik tutum ölçeği}

Öğretmen adaylarının mesleğe yönelik tutumlarını belirlemek amacıyla Çetin (2006) tarafından geliştirilen Öğretmenlik Mesleğine Yönelik Tutum Ölçeği kullanılmıştır. Ölçek beşli likert tipinde hazırlanan 35 maddeden oluşmaktadır. Bir grubun ölçekten daha yüksek puana sahip olması, o grubun öğretmenlik mesleğine yönelik tutumunun daha olumlu olduğunu göstermektedir. Ölçek geliştirme çalışmasında sevgi, değer ve uyum alt boyutlarının güvenirlik katsayıları sırasıyla $0,95,0,81$ ve 0,76 ve ölçeğin tamamı güvenirlik katsayısı 0,95 olarak hesaplanmıştır. Çalışmada ölçeğin Cronbach Alpha güvenirlik katsayıları sevgi boyutunda 0,92, değer boyutunda 0,86 , uyum boyutunda 0,83 ve toplam ölçek için 0,94 olarak hesaplanmıştır.

\section{Öğretmen öz-yeterlik ölçeği}

Öğretmen adaylarının mesleğe ilişkin öz-yeterlik algılarını belirlemek için Tschannen-Moran ve Woolfolk-Hoy (2001) tarafından geliştirilen ve Baloğlu ve Karadağ (2008) tarafından Türkçeye uyarlanan Öğretmen Yetkinlik Ölçeği kullanılmıştır. Beşli likert tipindeki ölçekte 24 madde bulunmaktadır. Bir grubun ölçekten daha yüksek puana sahip olması, o grubun öğretmen özyeterlik algısının daha olumlu olduğunu göstermektedir. Uyarlama çalışmasında ölçeğin orijinal yapıdan farklı olarak üç boyut yerine 5 boyutlu bir yapıda olduğu belirtilmektedir. Ölçeğin alt boyutları için güvenirlik katsayısı 0,66 ile 0,79 arasında değişmekte ve toplam ölçek içinse 0,90 olarak bulunduğu görülmektedir. Aynı ölçme aracının yapısı doğrulayıcı faktör analizi ile 
yeniden İpek ve Demirel (2012) tarafından sınanmış ve orijinal ölçekteki gibi üç faktörlü yap1 doğrulanmıştır. Çalışmamız için gerçekleştirilen doğrulayıcı faktör analizinde de 3 boyutlu orijinal yapı doğrulanmıştır. Ölçeğin diğer bir uyarlamasının (Çapa, Çakıroğlu ve Sarıkaya, 2005) 3 boyutlu olarak gerçekleştirildiği de göz önüne alınarak, ölçek çalışmada 3 boyut olarak değerlendirilmiştir. Ölçeğin Cronbach alpha iç tutarlık güvenirlik katsayılarına bakıldığında öğrenci katılımı boyutu için 0,74 , ögretim stratejisi alt boyutu için 0,78 ve sınıf yönetimi alt boyutu için ise 0,74 ve toplam ölçek için 0,90 olarak hesaplanmıştır.

\section{Verilerin Toplanması ve Analizi}

Veriler toplanmaya başlamadan önce uygulama yapılan üniversitenin etik kurulundan etik kurul izni alınmıştır. Uygulama öncesi öğrencilere uygulama yönergesi okunmuş, verilerin gizliliği ve nasıl kullanılacağı açıklanmış, araştırmanın amacı hakkında kısaca bilgi verilmiştir. Veri toplama araçlarından hazırlanan form, araştırmacılar tarafından sınıf ortamında araştırmaya katılmaya gönüllü öğrencilere uygulanmıştır.

Araştırmadan elde edilen veriler bilgisayar ortamına aktarılmış ve Öğretmenlik Mesleğine Yönelik Tutum Ölçeğindeki 10 olumsuz maddedeki puanlar ters çevrilmiştir. Araştırmanın amaçları doğrultusunda verilerin analizinde çok değişkenli istatistik varsayımları karşılandığı görülmüştür. Kullanılan ölçeklerin alt boyutlarından elde edilen puanlar ve pedagojik formasyon eğitimi alma istekleri ve pedagojik formasyon eğitimden memnuniyet düzeyleri sadece korelasyonları incelemede kullanılmış, diğer analizlerde bağımlı değişkenleri çok fazla artırmamak adına ölçek toplam puanları kullanılmıştır.

Bağımlı değişken olarak ele alınan öğretmenlik mesleğine yönelik tutum ve öğretmen öz-yeterlik inancının birbiri ilişkili olması nedeniyle grup düzeylerinin farklılıkları çok değişkenli varyans analizi ile (MANOVA) ile test edilmiştir. MANOVA test istatistiklerinden en çok kullanılan ve diğerlerinde göre güçlü yanları bulunan (Tabachnick ve Fidell, 2006; Stevens, 2009) Wilks' Lambda ( $\lambda$ ) test sonuçları kullanılmıştır. İki bağımlı değişkenin birlikte ele alındığı MANOVA analizinden elde edilen sonucun aynısı tek değişkenli varyans analizi (ANOVA) sonucunda görülmeyebilir. Bu yüzden bağımlı değişkenlerin tek tek ANOVA testine tabi tutulması gereklidir. Bu sayede bağımlı değişkenlerin birlikte ele alındığında görülen durumun, ayrı ayrı ele alındıklarında varlığı incelenmiştir.

Hangi gruplar arasında farklılık olduğunu belirlemek için varyansların eşit olması durumunda Bonferroni, eşit olmaması durumunda ise Tamhane T2 istatistiğine başvurulmuştur. Tüm analizlerde gruplar arası kovaryans matrisinin eşit olduğu görülmüştür $(p<0,001$, Tabachnick ve Fidell, 2006). Varyans analizi sonuçları etki büyüklügü ile ifade edilerek daha da anlamlı hale getirilmeye çalışılmıştır. Buna göre kısmi eta kare $\left(\eta^{2}\right)$ etki büyüklügüu, $\prod^{2}<0,06$ küçük, $0,06 \leq \eta^{2}<, 014$ orta ve $\prod^{2} \geq 0,14$ olması halinde büyük etki olduğu yorumu getirilmiştir (Cohen,1977, Akt:Stevens, 2009).

\section{Bulgular}

Araştırmanın birinci alt amacına ilişkin katılımcıların öğretmen öz yeterlilik algıları ile mesleğe yönelik tutumları arasındaki ilişki incelenmiştir. Üçer alt boyuttan oluşan ölçme araçları arasındaki ilişkiye yönelik bulgular Tablo 2'de verilmiştir. 
Tablo 2. Tutum ve Öz-Yeterlik Ölçekleri, Formasyon İstek ve Memnuniyet Düzeyleri Arası Korelasyon Katsayıları

\begin{tabular}{|c|c|c|c|c|c|c|c|c|c|}
\hline & $\begin{array}{l}\text { Tutum } \\
\text { (Sevgi) }\end{array}$ & $\begin{array}{l}\text { Tutum } \\
\text { (Değer) }\end{array}$ & $\begin{array}{l}\text { Tutum } \\
\text { (Uyum) }\end{array}$ & $\begin{array}{c}\text { Öz-Yet } \\
\text { (Öğr.Kat.)(C }\end{array}$ & $\begin{array}{c}\text { Öz-Yet } \\
\text { (Öğ. Stra.) }\end{array}$ & $\begin{array}{c}\text { Öz-Yet } \\
\text { (Snf.Yön.) }\end{array}$ & $\begin{array}{c}\text { Tutum } \\
\text { (Toplam) }\end{array}$ & $\begin{array}{c}\text { Öz-Yet } \\
\text { (Toplam) }\end{array}$ & $\begin{array}{l}\text { For. } \\
\text { İstek }\end{array}$ \\
\hline Tutum (Değer) &, 525 & & & & & & & & \\
\hline Tutum (Uyum) & 666 & ,416 & & & & & & & \\
\hline Öz-Yet(Öğr.Kat.) & 293 & 301 & , 125 & & & & & & \\
\hline Öz-Yet(Öğ. Stra.) & ,275 & ,284 & ,116 & ,717 & & & & & \\
\hline Öz-Yet(Snf. Yön.) & ,298 & 299 & ,140 & 669 & 706 & & & & \\
\hline Tutum (Toplam) & ,969 & 670 & ,778 & ,299 & ,280 & ,305 & & & \\
\hline Öz-yeterlik(Toplam) & ,323 & ,330 & ,142 & 887 & 906 & 888 & ,330 & & \\
\hline For. İstek & ,482 & ,296 & ,368 & ,111 & , 107 & ,138 & ,485 & 133 & \\
\hline For. Memnuniyet &, 372 & 251 & ,284 & ,114 & ,109 & ,137 &, 38 & ,134 &, 573 \\
\hline
\end{tabular}

Öğr.Kat.=Öğrenci Katılımı, Öğ. Stra. $=$ Öğretim Stratejisi,

Snf. Yön.=Sınıf Yönetimi, For.=Formasyon

Tablo 2'de bulunan değerlerin tamamında anlamlı bir ilişki $(\mathrm{p}<0,01)$ olduğu görülmüştür. Pearson korelasyon katsayılarına bakıldığında ölçekler ve aynı ölçekte bulunan alt boyutlar arasında 0,67 ile 0,97 arasında yüksek düzeyde ilişki görülmüştür. Farklı ölçeklerin alt boyutları arasında ise düşük ilişki olduğu görülmüştür. Öğretmenlik mesleğine yönelik tutum ve öğretmen öz-yeterlik ölçek toplam puanları ele alındığında değişkenler arasında 0,33 düzeyinde orta seviyede pozitif bir ilişki olduğu gözlenmiştir. Formasyon öğrenimine katılımdan duyulan memnuniyet ile istek arasında orta düzey bir ilişki var iken bu değişkenlerin öğretmenlik mesleğine yönelik tutumla orta, öğretmen öz-yeterlik algısı ile çok düşük bir ilişkiye sahip olduğu gözlenmiştir.

Çalışmanın 2. alt amacı çerçevesinde öğretmen adaylarının mesleğe yönelik tutum ve mesleki öz yeterlilik algıları, kayıtlı oldukları programlar açısından karşılaştırılmış ve bulgular Tablo 3'te sunulmuştur.

Tablo 3. Program Değişkenine Göre Varyans Analizi ve Varyans Homojenliği

\begin{tabular}{lllllc}
\hline Analiz & Bağımlı Değişken & $\mathrm{F}$ & $\mathrm{p}$ & Etki Büyüklüğü & Varyans Eşitliği (p) \\
\cline { 1 - 1 } MANOVA $(\lambda)$ & Tutum ve Öz-yeterlik & 14,680 &, 000 &, 070 & - \\
\cline { 1 - 3 } ANOVA & Tutum & 18,696 &, 000 &, 087 &, 132 \\
& Öz-yeterlik & 6,409 &, 000 &, 032 &, 000 \\
\hline
\end{tabular}

Tablo 3'deki MANOVA için gerçekleştirilen Wilks' Lambda $(\lambda)$ test sonuçlarına bakıldığında, programa göre öğretmen öz-yeterlik ve öğretmenlik mesleğine yönelik tutum puanlarının anlamlı bir şekilde farklılaştığını göstermektedir $\left(\mathrm{F}_{(8,1560)}=14,68, \mathrm{p}<0,01\right)$. Bağımlı değişkenler birlikte ele alındığında program değişkeninin bağımlı değişkenlerin üzerinde etki büyüklüğü değerinin orta düzeyde olduğu görülmektedir.

Bağımlı değişkenlerin tek tek ele alındığı ANOVA analizinde, öğretmenlik mesleğine yönelik tutum $\left(\mathrm{F}_{(4,781)}=18,696, \mathrm{p}<0,01\right)$ ve öğretmen öz-yeterlik alg1s1 puanlarının $\left(\mathrm{F}_{(4,781)}=6,409\right.$, p $<0,01)$ program değişkenine göre anlamlı bir şekilde farklılaştığı görülmüştür. Program değişkenin tutum puanları üzerinde orta, öz-yeterlik puanları üzerinde ise küçük düzeyde etkiye sahip olduğu görülmektedir. Farklılıkların hangi programlar arasında olduğunu incelemek için tutum puanlarının gruplar arası varyansları homojen dağıldığından ( $>00,05)$ Bonferroni, öz- 
yeterlik puanlarının varyansları homojen olmaması nedeniyle Tamhanes' T2 yöntemleriyle ikili karşılaştırmalar yapılmış ve bulgular Tablo 4'te sunulmuştur.

Tablo 4. Program Değişkenine Göre Ölçek Puanları ve Programlar Arası İkili Karşılaştırmalar

\begin{tabular}{lllcllc}
\hline Bağımlı Değişken & Program & $\mathrm{N}$ & $\bar{X}$ & Ss & Anlamlı Fark & $\mathrm{p}$ \\
\hline Tutum & Eğitim & 162 & 146,81 & 19,89 & Eğitim>Besyo &, 000 \\
& İlahiyat & 136 & 145,69 & 21,41 & İlahiyat>Besyo &, 000 \\
& Besyo & 87 & 126,22 & 22,69 & & \\
& Fen-Edebiyat & 212 & 146,06 & 22,40 & Fen Edebiyat>Besyo &, 000 \\
& P. Formasyon & 189 & 148,57 & 20,26 & P.Formasyon>Besyo &, 000 \\
Öz-yeterlik & Ĕgitim & 162 & 93,77 & 10,23 & Eğitim>İlahiyat &, 003 \\
& İlahiyat & 136 & 89,18 & 11,18 & &, 019 \\
& Besyo & 87 & 94,55 & 13,18 & Besyo>İlahiyat &, 001 \\
& Fen-Edebiyat & 212 & 94,17 & 11,24 & Fen-Edebiyat>Illahiyat &, 000 \\
\hline
\end{tabular}

Tablo 4'de bulunan değerlere bakıldığında tüm öğretmen yetiştiren programlardaki öğretmenlik mesleğine yönelik tutum puanlarının Besyo'daki öğrencilerden anlamlı bir şekilde yüksek olduğu görülmektedir. Öğretmen öz-yeterlik puanlarına bakıldığında ise İlahiyat öğrencilerinin öz-yeterlik algıları diğer birimlerde öğrenim gören öğrencilerden anlamlı bir şekilde daha düşük olduğu görülmüştür. Diğer programlar arasında anlamlı farklık görülmemiştir.

Çalışmanın 3. alt amacı kapsamında, öğretmen adaylarının mesleğe yönelik tutum ve öz yeterlilik algıları yaş değişkeni açısından karşılaştırılmış ve bulgular Tablo 5 'te sunulmuştur.

Tablo 5. Yaş Değişkenine Göre Varyans Analizi ve Varyans Homojenliği

\begin{tabular}{llcccc}
\hline Analiz & Bağımlı Değişken & $\mathrm{F}$ & $\mathrm{p}$ & Etki Büyüklüğ̈̈ & Varyans Eşitliği (p) \\
\cline { 1 - 3 } MANOVA $(\lambda)$ & Tutum ve Öz-yeterlik & 2,458 &, 012 &, 012 & - \\
\cline { 1 - 2 } ANOVA & Tutum & 3,330 &, 010 &, 017 &, 231 \\
& Öz-yeterlik & 2,414 &, 048 &, 012 &, 081 \\
\hline
\end{tabular}

Tablo 5'deki MANOVA için gerçekleştirilen Wilks' Lambda $(\lambda)$ test sonuçlarına bakıldığında, öğrenci yaşına göre öğretmen öz-yeterlik ve öğretmenlik mesleğine yönelik tutum puanlarının anlamlı bir şekilde farklılaştığını göstermektedir $\left(\mathrm{F}_{(8,1558)}=2,458, \mathrm{p}<0,05\right)$. Bağımlı değişkenler birlikte ele alındığında yaş değişkeninin bağımlı değişkenlerin üzerinde etki büyüklüğü değerinin küçük olduğu görülmektedir.

Bağımlı değişkenler tek tek ele alındığında öğretmenlik mesleğine yönelik tutum $\left(F_{(4,780)}=3,33, p<0,05\right)$ ve öğretmen öz-yeterlik algısı $\left(F_{(4,780)}=2,414, p<0,05\right)$ puanlarının yaş değişkenine göre anlamlı bir şekilde farklılaştığ görülmüştür. Yaş değişkeninin puanlar üzerinde etki büyüklüğüne bakıldığında her iki bağımlı değişken için de küçük etkisi olduğu görülmektedir. Puanlar arasındaki farkın hangi yaş grubu arasında olduğunu incelemek gruplar arası varyansların homojen eşit olması dolayısıyla $(p>0,05)$ Bonferroni yöntemiyle ikili karşılaştırmalar yapılmış ve bulgular Tablo 6' da sunulmuştur. 
Tablo 6. Yaş Değişkenine Göre Ölçek Puanları ve Yaş Grupları Arası İkili Karşılaştırmalar

\begin{tabular}{lcccccc}
\hline Bağımlı Değişken & Yaş & $\mathrm{N}$ & $\bar{X}$ & $\mathrm{Ss}$ & Anlamlı Fark & $\mathrm{p}$ \\
\hline Tutum & $\leq 20$ & 51 & 144,20 & 21,00 & & \\
& $21-25$ & 600 & 143,36 & 22,58 & & \\
& $26-30$ & 58 & 148,76 & 19,63 & & \\
& $31-35$ & 47 & 154,43 & 19,86 & $(31-35)>(21-25)$ & \\
& $\geq 36$ & 29 & 145,02 & 20,90 & & \\
\hline Öz-yeterlik & $\leq 20$ & 51 & 92,91 & 10,13 & & \\
& $21-25$ & 600 & 92,85 & 11,14 & & \\
& $26-30$ & 58 & 96,66 & 10,22 & & \\
& $31-35$ & 47 & 94,99 & 8,64 & & \\
& $\geq 36$ & 29 & 96,16 & 11,93 & & \\
\hline
\end{tabular}

Yaş gruplarına göre ölçek puanlarının ele alındığı Tablo 6'da bulunan değerlere bakıldığında sadece bir karşılaştırmada gruplar arası anlamlı fark görülmüştür. 31-35 yaş grubundaki öğretmen adaylarının, 21-25 yaş grubundaki öğretmen adaylarına göre öğretmenlik mesleğine yönelik tutum puanları anlamlı bir şekilde yüksek olduğu görülmüştür $(p<0,05)$. Öğretmen öz-yeterlik puanlarına bakıldığında ise yaş grupları arasında anlamlı bir farklılık görülmemiştir.

Çalışmanın 4. alt amacı kapsamında öğretmen adaylarının mesleğe yönelik tutumları ve öz yeterlilik algıları cinsiyetleri açısından karşılaştırılmış ve bulgular Tablo 7'de sunulmuştur.

Tablo 7. Cinsiyet Değişkenine Göre Varyans Analizi

\begin{tabular}{lcccc}
\hline Analiz & Bağımlı Değişken & $\mathrm{F}$ & $\mathrm{p}$ & Etki Büyüklüğü \\
\cline { 1 - 2 } MANOVA $(\lambda)$ & Tutum ve Öz-yeterlik & 33,259 &, 000 &, 079 \\
\cline { 1 - 2 } ANOVA & Tutum & 55,911 &, 000 &, 067 \\
& Öz-yeterlik &, 227 &, 634 &, 000 \\
\hline
\end{tabular}

Tablo 7'deki MANOVA için gerçekleştirilen Wilks' Lambda $(\lambda)$ test sonuçlarına bakıldığında, cinsiyete göre öğretmen öz-yeterlik ve öğretmenlik mesleğine yönelik tutum puanlarının anlamlı bir şekilde farklılaştığını göstermektedir $\left(\mathrm{F}_{(2,779)}=33,259, \mathrm{p}<0,01\right)$. Bağımlı değiş̧kenler birlikte ele alındığında cinsiyet değişkeninin bağımlı değişkenlerin üzerinde etki büyüklüğü değerinin orta düzeyde olduğu görülmektedir.

Tablo 8. Cinsiyet Değişkenine Göre Ölçek Puanları

\begin{tabular}{lcccc}
\hline Bağımlı Değişken & Cinsiyet & $\mathrm{N}$ & $\bar{X}$ & Ss \\
\hline \multirow{2}{*}{ Tutum } & Kadın & 527 & 148,51 & 20,77 \\
& Erkek & 255 & 136,26 & 22,85 \\
\multirow{2}{*}{ Öz-yeterlik } & Kadın & 527 & 93,23 & 10,53 \\
& Erkek & 255 & 93,62 & 11,80 \\
\hline
\end{tabular}

Bağımlı değişkenler tek tek ele alındığında ise cinsiyete göre öğretmenlik mesleğine yönelik tutumun $\left(\mathrm{F}_{(1,780)}=55,911 \mathrm{p}<0,01\right)$ kadın öğretmen adayları lehine anlamlı bir şekilde farklılaştığ1 ancak öğretmen öz-yeterlik alg1S1 $\left(\mathrm{F}_{(1,780)}=0,227, \mathrm{p}>0,05\right)$ puanlarında anlamlı bir fark olmadığı görülmüştür. Cinsiyet değişkeninin tutum puanları üzerinde etki büyüklügüne bakıldığında orta düzeyde etkisi olduğu görülmektedir. 
Çalışmanın 5. alt amacı kapsamında öğretmen adaylarının mesleğe yönelik tutumları ve öz yeterlilik algıları medeni durumları açısından karşılaştırılmış ve bulgular Tablo 9'da sunulmuştur.

Tablo 9. Medeni Durum Değişkenine Göre Varyans Analizi

\begin{tabular}{llccc}
\hline Analiz & Bağımlı Değişken & $\mathrm{F}$ & $\mathrm{p}$ & Etki Büyüklüğü \\
\cline { 1 - 4 } MANOVA $(\lambda)$ & Tutum ve Öz-yeterlik & 6,659 &, 001 &, 017 \\
\cline { 1 - 3 } ANOVA & Tutum & 10,408 &, 001 &, 013 \\
& Öz-yeterlik & 7,115 &, 008 &, 009 \\
\hline
\end{tabular}

Medeni durum değişkeni için gerçekleştirilen, Tablo 9'da bulunan MANOVA testine ait Wilks' Lambda $(\lambda)$ sonuçlarına bakıldığında medeni duruma göre öğretmen öz-yeterlik ve öğretmenlik mesleğine yönelik tutum puanlarının anlamlı bir şekilde farklılaştığı görülmektedir $\left(\mathrm{F}_{(2,773)}=6,659, \mathrm{p}<0,01\right)$. Bağımlı değişkenler birlikte ele alındığında yaş değişkeninin bağımlı değişkenlerin üzerinde etki büyüklüğünün küçük olduğu görülmektedir.

Tablo 10. Medeni Durum Değișkenine Göre Ölçek Puanları

\begin{tabular}{llccc}
\hline Bağımlı Değişken & Cinsiyet & N & $\bar{X}$ & Ss \\
\hline Tutum & Evli & 105 & 151,09 & 20,40 \\
& Bekar & 671 & 143,67 & 22,36 \\
Öz-yeterlik & Evli & 105 & 95,99 & 9,99 \\
& Bekar & 671 & 92,94 & 11,06 \\
\hline
\end{tabular}

Bağımlı değişkenler tek tek ele alındığında medeni durum göre öğretmenlik mesleğine yönelik tutumun $\left(F_{(1,774)}=10,408, p<0,01\right)$ ve öğretmen öz-yeterlik algısının $\left(F_{(1,774)}=7,115\right.$, $\mathrm{p}<0,01)$ evli öğretmen adayları lehine anlamlı bir şekilde farklılaştığı görülmüştür. Medeni değişkeninin tutum ve öz-yeterlik puanları üzerinde küçük düzeyde etki büyüklüğüne sahip olduğu görülmektedir.

Çalışmanın 6. alt amacı kapsamında öğretmen adaylarının mesleğe yönelik tutumları ve öz yeterlilik algıları, öğretmenlik yapmayı öncelikli olarak görüp-görmemeleri açısından karşılaştırılmış ve bulgular Tablo 11'de sunulmuştur. “Öğretmenlik yapmak gelecekteki iş hayatı planınızda birinci önceliğiniz mi?" maddesine verilen Evet-Hayır yanıtları bağımsız değişken olarak ele alındığı MANOVA testinden elde edilen istatistikler Tablo 11'de verilmiştir.

Tablo 11. Öğretmenlik Mesleğini Önceleme Değişkenine Göre Varyans Analizi

\begin{tabular}{llccc}
\hline Analiz & Bağımlı Değişken & $\mathrm{F}$ & $\mathrm{p}$ & Etki Büyüklüğ̈̈ \\
\cline { 1 - 2 } MANOVA $(\lambda)$ & Tutum ve Öz-yeterlik & 74,500 &, 000 &, 162 \\
\cline { 1 - 3 } ANOVA & Tutum & 149,016 &, 000 &, 162 \\
& Öz-yeterlik & 11,141 &, 001 &, 014 \\
\hline
\end{tabular}

MANOVA testine ait Wilks' Lambda $(\lambda)$ sonuçlarına bakıldığında, öğretmenliği önceleme değişkenine göre öğretmen öz-yeterlik ve öğretmenlik mesleğine yönelik tutum puanlarının anlamlı bir şekilde farklılaştığını göstermektedir $\left(\mathrm{F}_{(2,768)}=74,5, \mathrm{p}<0,01\right)$. Bağımlı değişkenler birlikte ele alındığında yaş değişkeninin bağımlı değişkenlerin üzerinde etki büyüklüğünün büyük olduğu görülmektedir. 
Tablo 12. Öğretmenlik Mesleğini Önceleme Değişkenine Göre Ölçek Puanları

\begin{tabular}{llccc}
\hline Bağımlı Değişken & Öncelik & N & $\bar{X}$ & Ss \\
\hline \multirow{2}{*}{ Tutum } & Evet & 610 & 149,29 & 19,81 \\
& Hayır & 161 & 127,22 & 22,49 \\
Öz-yeterlik & Evet & 610 & 94,09 & 10,85 \\
& Hayır & 161 & 90,89 & 10,75 \\
\hline
\end{tabular}

Bağımlı değişkenler tek tek ele alındığında öğretmenlik mesleğine yönelik tutumun $\left(F_{(1,769)}=149,016, \quad p<0,01\right)$ ve öğretmen öz-yeterlik algısının $\quad\left(F_{(1,769)}=11,141, \quad p<0,01\right)$ öğretmenlik mesleğini birinci öncelikli olarak yapmayı düşünen öğretmen adayları lehine anlamlı bir şekilde farklılaştığı görülmüştür. Öğretmenlik mesleğini önceleme değişkeninin tutum puanları üzerinde yüksek, öz-yeterlik puanları üzerinde ise küçük etki büyüklüğüne sahip olduğu görülmektedir.

Çalışmanın 7. alt amacı kapsamında öğretmen adaylarının mesleğe yönelik tutumları ve öz yeterlilik algıları öğrenim durumları açısından karşılaştıılmış ve bulgular Tablo 13'te sunulmuştur.

Tablo 13. Öğrenim Durumu Değişkenine Göre Varyans Analizi ve Varyans Homojenliği

\begin{tabular}{llcccc}
\hline Analiz & Bağımlı Değişken & $\mathrm{F}$ & $\mathrm{p}$ & Etki Büyüklüğü & Varyans Eşitliği $(\mathrm{p})$ \\
\cline { 1 - 5 } MANOVA $(\lambda)$ & Tutum ve Öz-yeterlik & 2,406 &, 026 &, 009 & - \\
\cline { 1 - 3 } ANOVA & Tutum & 3,665 &, 012 &, 014 &, 068 \\
& Öz-yeterlik & 2,131 &, 095 &, 008 &, 427 \\
\hline
\end{tabular}

Tablo 13'deki MANOVA için gerçekleştirilen Wilks' Lambda $(\lambda)$ test sonuçlarına bakıldığında, öğrenim durumuna göre öğretmen öz-yeterlik ve öğretmenlik mesleğine yönelik tutum puanlarının anlamlı bir şekilde farklılaştığı görülmektedir $\left(F_{(6,1560)}=2,406, p<0,05\right)$. Bağımlı değişkenler birlikte ele alındığında öğrenim durumu değişkeninin bağımlı değişkenlerin üzerinde etki büyüklüğünün küçük olduğu görülmektedir.

Bağımlı değişkenler tek tek ele alındığında öğrenim durumu değişkenine göre öğretmenlik mesleğine yönelik tutum puanlarının anlamlı bir şekilde farklılaştığı $\left(\mathrm{F}_{(3,781)}=3,665\right.$, $\mathrm{p}<0,05)$ ancak öğretmen öz-yeterlik alg1s1 puanlarında farkl1lık olmadığı $\left(\mathrm{F}_{(3,781)}=2,131, \mathrm{p}>0,05\right)$ görülmüştür. Öğrenim durumu değişkeninin tutum puanları üzerinde etki büyüklüğünün küçük olduğu görülmektedir. Tutum puanları arasındaki farkın hangi öğrenim durumu grupları arasında olduğunu incelemek gruplar arası varyansların homojen eşit olması dolayısıyla $(p>0,05)$ Bonferroni yöntemiyle ikili karşılaştırmalar yapılmıştır.

Tablo 14. Öğrenim Durumu Değişkenine Göre Ölçek Puanları ve Öğrenim Durumu Grupları Arası İkili Karşılaştırmalar

\begin{tabular}{llccccc}
\hline Bağımlı Değişken & Öğrenim & $\mathrm{N}$ & $\bar{X}$ & $\mathrm{Ss}$ & Anlamlı Fark & $\mathrm{p}$ \\
\hline Tutum & Lisans Öğr. & 619 & 143,60 & 22,47 & & \\
& Lisans Mzn. & 139 & 149,86 & 19,78 & Lisans Mzn.>Lisans Öğr. & 0,016 \\
& L.Üstü Öğr. & 19 & 139,18 & 22,67 & & \\
& L.Üstü Mzn. & 8 & 138,04 & 28,78 & & \\
\hline Öz-yeterlik & Lisans Öğr. & 619 & 92,94 & 11,04 & & \\
& Lisans Mzn. & 139 & 95,39 & 10,48 & & \\
& L.Üstü Öğr. & 19 & 92,89 & 9,88 & & \\
& L.Üstü Mzn. & 8 & 96,38 & 9,92 & & \\
& & & & & & \\
\end{tabular}


Öğrenim durumu gruplarına göre ölçek puanlarının ele alındığı Tablo 14'de bulunan değerlere bakıldığında sadece bir karşılaştırmada gruplar arası anlamlı fark görülmüştür. Lisans mezunu öğretmen adaylarının lisans öğrencisi olan öğretmen adaylarına göre öğretmenlik mesleğine yönelik tutum puanları anlamlı bir şekilde yüksek olduğu görülmüştür $(p<0,05)$.

Çalışmanın 8. alt amacı kapsamında öğretmen adaylarının mesleğe yönelik tutumları ve öz yeterlilik algıları bir işte çalışıp çalışmama durumlarına göre karşılaştırılmış ve sonuçlar Tablo 15'te sunulmuştur.

Tablo 15. Çalışma Durumu Değişkenine Göre Varyans Analizi ve Varyans Homojenliği

\begin{tabular}{llcccc}
\hline Analiz & Bağımlı Değişken & $\mathrm{F}$ & $\mathrm{p}$ & Etki Büyüklüğü & Varyans Eşitliği $(\mathrm{p})$ \\
\cline { 1 - 1 } MANOVA $(\lambda)$ & Tutum ve Öz-yeterlik & 3,720 &, 000 &, 019 & - \\
\cline { 1 - 3 } ANOVA & Tutum & 5,551 &, 000 &, 028 &, 645 \\
& Öz-yeterlik & 2,960 &, 019 &, 015 &, 836 \\
\hline
\end{tabular}

Tablo 15'de bulunan MANOVA için gerçekleştirilen Wilks' Lambda $(\lambda)$ test sonuçlarına bakıldığında, çalışma durumuna göre öğretmen öz-yeterlik ve öğretmenlik mesleğine yönelik tutum puanlarının anlamlı bir şekilde farklılaştı̆̆ı görülmektedir $\left(\mathrm{F}_{(8,1538)}=3,72, \mathrm{p}<0,01\right)$. Bağımlı değişkenler birlikte ele alındığında yaş değişkeninin bağımlı değişkenlerin üzerinde etki büyüklüğünün küçük olduğu görülmektedir.

Bağımlı değişkenler tek tek ele alındığında öğretmenlik mesleğine yönelik tutum $\left(F_{(4,770)}=5,551, p<0,01\right)$ ve öğretmen öz-yeterlik algısı $\left(F_{(4,770)}=2,96, p<0,05\right)$ puanlarının çalışma durumu değişkenine göre anlamlı bir şekilde farklılaştığı görülmüştür. Etki büyüklüklerine bakıldığında ise çalışma durumu değişkeninin puanlar üzerinde küçük etkisi olduğu görülmektedir. Görülen farkın hangi öğrenim durumu grupları arasında olduğunu incelemek gruplar arası varyansların homojen eşit olması dolayısıyla $(p>0,05)$ Bonferroni yöntemiyle ikili karşılaştırmalar yapılmış ve bulgular Tablo 16 ' da verilmiştir.

Tablo 16. Çalışma Durumu Değişkenine Göre Ölçek Puanları ve Çalışma Durumu Grupları Arası İkili Karşılaştırmalar

\begin{tabular}{llccccc}
\hline Bağımlı Değişken & Çalışma & $\mathrm{N}$ & $\bar{X}$ & $\mathrm{Ss}$ & Anlamlı Fark & $\mathrm{p}$ \\
\hline Tutum & Çalı̧̧mıor & 608 & 145,0666 & 22,04502 & Çalışmıyor>İşçi &, 000 \\
& İşçi & 22 & 125,4727 & 19,02332 & & \\
& D.Memur & 37 & 142,5724 & 22,49001 & D.Memur >İş̧̧i &, 04 \\
& Ücr.Öğrt & 15 & 157,2374 & 24,38812 & Ücr.Öğrt > İşçi &, 000 \\
& Diğer & 93 & 144,8185 & 21,64318 & Diğer >İşçi &, 002 \\
\hline Öz-yeterlik & Çalışmıor & 608 & 93,0683 & 10,84893 & Ücr.Öğrt >Çalışmıyor &, 036 \\
& İşçi & 22 & 90,5431 & 12,30983 & & \\
& D.Memur & 37 & 92,9296 & 12,18716 & &, 031 \\
& Ücr.Öğrt & 15 & 101,3730 & 10,40812 & Ücr.Öğrt >İşçi & \\
& Diğer & 93 & 94,8489 & 10,27626 & & \\
\hline
\end{tabular}

Çalışma durumu gruplarına göre ölçek puanlarının ele alındığı Tablo 16'da bulunan değerlere bakıldığında, işçi olarak çalışan öğretmen adaylarının tutum puanlarının diğer çalışma gruplarındaki öğretmen adaylarından anlamlı bir şekilde daha düşük olduğu görülmüştür $(\mathrm{p}<, 05)$. Öz-yeterlik puan karşılaştırmaları incelendiğinde ise ücretli öğretmen olarak çalışan öğretmen adaylarının, çalışmayan ve işçi olarak çalışan öğretmen adaylarından anlamlı bir şekilde daha yüksek puana sahip olduğu görülmüştür $(\mathrm{p}<0,05)$. 
Çalışmanın 9. alt amacı kapsamında öğretmen adaylarının mesleğe yönelik tutumları ve öz-yeterlik algıları gelir düzeylerine göre karşılaştırılmış ve bulgular Tablo 17'de sunulmuştur.

Tablo 17. Gelir Düzeyi Değişkenine Göre Varyans Analizi ve Varyans Homojenliği

\begin{tabular}{llcccc}
\hline Analiz & Bağımlı Değişken & $\mathrm{F}$ & $\mathrm{p}$ & Etki Büyüklüğü & Varyans Eşitliği $(\mathrm{p})$ \\
\cline { 1 - 5 } MANOVA $(\lambda)$ & Tutum ve Öz-yeterlik & 2,784 &, 005 &, 016 & - \\
\cline { 1 - 2 } ANOVA & Tutum & 2,326 &, 055 &, 014 &, 051 \\
& Öz-yeterlik & 2,129 &, 076 &, 013 &, 989 \\
\hline
\end{tabular}

Tablo 17'de bulunan, MANOVA için gerçekleştirilen Wilks' Lambda $(\lambda)$ test sonuçlarına bakıldığında, gelir düzeyine göre öğretmen öz-yeterlik ve öğretmenlik mesleğine yönelik tutum puanlarının anlamlı bir şekilde farklılaştığı görülmektedir $\left(\mathrm{F}_{(8,1340)}=2,784\right.$, $\mathrm{p}<0,01)$. Bağımlı değişkenler birlikte ele alındığında yaş değişkeninin bağımlı değişkenlerin üzerinde etki büyüklüğünün küçük olduğu görülmektedir.

Bağımlı değişkenler tek tek ele alındığında öğretmenlik mesleğine yönelik tutum $\left(F_{(4,671)}=2,326, p>0,05\right)$ ve öğretmen öz-yeterlik algıs1 $\left(F_{(1,671)}=2,129, p>0,05\right)$ puanlarının gelir durumu değişkenine göre anlamlı bir şekilde farklılaşmadığı görülmüştür.

\section{Tartışma ve Sonuç}

$\mathrm{Bu}$ araştırmada öğretmenlik mesleğine kaynaklık eden farklı fakülte ve programlarda eğitim gören öğretmen adaylarının öğretmenlik mesleğine yönelik tutumları ve öğretmen öz-yeterlik algıları incelenmiştir. Araştırma sonuçlarına göre öğretmenlik mesleğine yönelik tutum ve öğretmen öz-yeterlik algısı arasında orta düzeyde pozitif bir ilişki görülmüştür. Aynı özellikleri araştıran Demirtaş, Cömert ve Özer (2011) ve Dadand1, Kalyon ve Yazıcı (2016) da iki değişken arasında anlamlı pozitif ilişki olduğunu tespit etmişlerdir. Güney Afrika ve Finlandiya'da öğretmen adayları ile yapılan çalışmada kaynaştırma eğitimine ilişkin olumlu tutuma sahip olan adayların, bu müfredatı uygulama konusunda da kendilerini daha yetkin hissettikleri belirlenmiştir (Savolainen, Engelbrecht, Nel ve Malinen, 2012). Sonuç olarak öğretmenlik mesleğine ilişkin bu iki içsel faktörün birbirlerini beslediği söylenebilir. Kendini öğretmenlikte yeterli olarak algılayan öğretmen adayının mesleğini daha fazla benimsediği veya mesleğinde yönelik olumlu tutumlar besleyen öğretmen adayının mesleğinde kendini daha yeterli hissettiği sonucuna varılabilir. Elde edilen bulguların bu iki değişkenin ilişkili olduğunu göstermesi nedeniyle öğretmenlik mesleğine yönelik tutumları ve öğretmen öz-yeterlik algılarının birlikte incelenmesinin doğru olacağı düşünülmektedir.

Çalışmada yapılan tüm MANOVA sonuçları anlamlı çıkmıştır. Bu bulgu öğretmenlik mesleğine yönelik tutum ve öğretmen öz-yeterlik algılarının birlikte değiştiğine işaret etmektedir. Ayrıca araştırmada kullanılan tüm bağımsız değişkenlerin bağımlı değişkenler üzerinde etkili olduğu, özellikle fakülte ve cinsiyet değişkenlerinin orta düzeyde, öğretmenliği önceleme değişkenin ise büyük etkiye sahip olduğu bulunmuştur. Öğretmen adaylarının öğretmenlik mesleğini birinci öncelik düşünmelerinin, mesleğe yönelik tutumları ve mesleki yeterlik algıları gibi mesleğe ilişkin içsel faktörlerden olması nedeniyle yüksek etkiye sahip olduğu söylenebilir.

Öğretmen adaylarının öğretmenlik mesleğine yönelik tutumların öğrenimlerini sürdürdükleri programlara göre farklılaştığı bulunmuştur. Farkın derecesi için etki büyüklüğüne bakıldığında ise orta yani önemsenmesi gereken düzeyde olduğu bulunmuştur. Farklılığın 
kaynağı incelendiğinde BESYO'da okuyan öğretmen adaylarının öğretmenlik mesleğine yönelik tutumlarının diğer tüm öğrenci gruplarından daha olumsuz olduğu ancak diğer fakülte/program öğrencileri arasında anlamlı bir farklılık olmadığı bulunmuştur. Bu konuda yapılan çalışmalar incelendiğinde, Sandıkçı ve Öncü'nün (2013) çalışmasında BESYO ve EF öğrencilerinin öğretmenlik mesleğine yönelik tutumun farklılaşmadığı bulunmuştur. BESYO'daki öğretmen adaylarının öğretiminde daha çok psiko-motor becerilerin gelişimi üzerinde durulmaktadır. Bu yüzden öğretmenlik mesleğine ilişkin duyuşsal özelliklerin diğer öğretmen adaylarına nazaran bir miktar geri planda kalmış olabileceği söylenebilir.

Öğretmen adaylarının öğretmenlik mesleğine yönelik tutumlarının karşılaştırıldığı diğer çalışmalarda ise EF-PFE karşılaştırması üzerinde durulmuştur. Polat (2013) ve Ömür ve Nartgün (2013)'ün çalışmasında, bu çalışma sonucundan farklı olarak PFE öğrencilerinin EF öğrencilerine göre öğretmenlik mesleğine yönelik daha olumlu tutuma sahip olduğu sonucuna ulaşılmıştır. Poyraz ve Çağırgan Gülten (2014) ise bu çalışmada elde edilen bulguyu destekler şekilde EF-PFE öğrencileri arasında anlamlı farklılık bulunmamıştır. Literatürdeki ilgili çalışmalar ve mevcut çalışma bulguları birlikte değerlendirildiğinde, bulguların farklılık gösterdiği bu nedenle öğretmenlik mesleğine ilişkin tutumda fakülte-programların rolünü belirlemek için daha fazla çalışmaya ihtiyaç duyulduğu görülmektedir.

Öğretmen adaylarının öğretmen öz-yeterlik algılarının da öğrenimlerini sürdürdükleri fakülteye göre farklılaştığı, bu farkın öğretmen öz-yeterlik algısı için küçük düzeyde olduğu bulunmuştur. Farklılığın kaynağı incelendiğinde ilahiyat fakültesinde okuyan öğretmen adaylarının diğer tüm öğrenci gruplarından daha düşük öğretmen öz-yeterlik algısına sahip olduğu görülmüştür. Araştırmaya katılan ilahiyat fakültesi öğrencilerinin çoğu 3. sınıfta bulunmaktadır. $\mathrm{Bu}$ sebeple henüz okul uygulamasına gitmemeleri nedeniyle kendilerini öğretmenlik için yeterli göremedikleri söylenebilir. Nitekim öğretmen adaylarının mesleki yeterlilik algılarının eğitim gördükleri programlardan ve daha önce uygulama deneyimi olup olmamasından etkilendiği belirtilmektedir (Loreman, Sharma ve Forlin, 2013). Ayrıca ilahiyat fakültesi öğrencilerinin din görevlisi olma imkânının olması kendilerini öğretmenlik için geliştirmemelerine yol açabilecek bir diğer durum olarak görülebilir. Fakülte/program bazında ikili karşılaştırma yapan araştırma sonuçlarına bakıldığında PFE-EF öğrencilerinin karşılaştırmaları bulunmaktadır. Öğretmen öz-yeterliğini inceleyen İpek ve Demirel (2012) PFE öğrencileri lehine bir sonuca ulaşmışken, Elkatmış, Demirbaş ve Ertuğrul (2013) ve Ilgaz, Çuhadar ve Bülbül'ün (2013) araştırmalarında ise bu çalışmada elde edilen bulguyu destekler şekilde PFE ile EF öğrencileri arasında anlamlı farklılık bulunmamıştır.

Öğretmen adaylarının öğretmenlik mesleğine yönelik tutum puanlarının yaşa göre anlamlı bir şekilde farklı olduğu ve bu farklılı̆̆ın 31-35 yaş grubuna ait tutum puanlarının 21-25 yaş grubuna göre anlamlı bir şekilde yüksek olmasından kaynaklandığ 1 görülmüştür. Ayrıca araştırmada bu bulguyu destekler şekilde lisans mezunu öğretmen adaylarının tutumlarının, lisans öğrencisi öğretmen adaylarına göre anlamlı bir şekilde yüksek olduğu da görülmüştür. Lisans öğrencilerinin yaş aralıkları 21-25 olarak düşünüldüğünde bu iki sonucun birbirini doğruladığ1 düşünülebilir. Polat'ın (2013) ulaştığ öğretmenlik mesleğine yönelik tutumun yaşa göre farklılık göstermediği bulgusu, bu çalışma bulgusu ile farklı olduğu görülmüştür. Mevcut çalışmadaki iki grubun farklı düzeylerde tutumlara sahip olmalarının nedeni büyük yaş grubun çoğunluğunun lisans mezunu olması ile açıklanabilir. Lisans mezunu öğretmen adayları 
öğretmen olmayı kendileri için son çare olarak görmeleri, dört elle sarılıp bu mesleği yapmak istiyor olmaları olasıdır. Bu sebeple de mesleğe ilişkin daha olumlu tutuma sahip olabilecekleri söylenebilir.

Öğretmen adaylarının öğretmen öz-yeterlik algılarının yaşa ve öğrenim durumuna göre farklılaşmadığı bulunmuştur. İlgili çalışmalar incelendiğinde Yaşar-Ekici'nin (2017) çalışmasında da öğretmen öz-yeterlik algılarının yaşa göre farklılaşmadığı bulgusu mevcut çalışma bulgusu ile benzerlik göstermektedir. Öğretmen adaylarının öz-yeterlik algılarının yaşam tecrübesi ile ilgili olmadığı söylenebilir. Öğretmenlik mesleği konusunda kendi yeterliliklerini sınama imkânı olmadığından ne kadar yeterli olduklarına ilişkin algıların benzer düzeyde olması, yaştan bağımsız olması beklendik bir sonuçtur.

Öğretmen adaylarının öğretmenlik mesleğine yönelik tutum puanlarının cinsiyete göre anlamlı bir şekilde farklı olduğu, bu farkın orta düzeyde etki büyüklüğüne sahip olduğu ve kadın öğretmen adaylarının daha olumlu tutuma sahip olduğu görülmüştür. Bu sonucun diğer çalışmaların genelinden elde edilen sonuç ile benzerlik gösterdiği söylenebilir. Erdamar, Aytaç, Türk ve Arseven (2016) tarafından yapılan 35 araştırmayı özetleyen meta analiz çalışmasında kadın öğretmen adaylarının mesleğe yönelik tutumlarını anlamlı bir şekilde daha yüksek olduğu sonucuna ulaşılmıştır. Toplumsal normlar bireylerin mesleğini belirlemede etkili olabilmektedir. $\mathrm{Bu}$ bağlamda öğretmenliğin kadınlar için daha uygun olduğuna ilişkin toplumsal algılar ve değerlendirmeler, kadınların kendilerinin de mesleğe daha uygun olduklarına inanmalarını etkilemiş olabilir. Ayrıca fedakârlık, ilgi ve şefkat mesleği olan öğretmenliğe ilişkin, kadınlarda da bu özelliklerin daha fazla olmasından dolayı kadınların olumlu tutma sahip olmalarının anlamlı bir sonuç olduğu söylenebilir.

Öğretmen adaylarının öğretmen öz-yeterlik algılarının cinsiyete göre farklılaşmadığı görülmüştür. Bu konuda yapılan çalışmalara bakıldığında Çetin (2017), Akça, Demir ve Yılmaz (2015) ve Ilgaz, Bülbül ve Çuhadar (2013) da öğretmen öz-yeterlilik algılarının cinsiyete göre farklılaşmadığını belirtmektedir. Cinsiyetin öğretmen adaylarının kendilerini öğretmenlik için yeterli görmelerinde önemli bir faktör olmadığg söylenebilir. Nitekim bir konuda kendini yeterli hissetme çoğunlukla somut göstergelere dayandırılarak açıklanmaktadır. Öğretmen adaylarının aynı teorik ve pratik eğitimden geçmeleri bu durumun bir sebebi olarak görülebilir. Ayrıca, özellikle uygulamada karşı cinsteki öğretmen ve öğretmen adaylarının, hemcinsleri öğretmenlerle ve kendileriyle benzer yeterliklere sahip olduklarını görmeleri cinsiyet bakımından öz-yeterlik algılarının benzer olmasına sebep olduğu söylenebilir.

Öğretmen adaylarının öğretmenlik mesleğine yönelik tutumlarının medeni duruma göre anlamlı bir şekilde farklı olduğu ve evli olan öğretmen adaylarının daha olumlu tutuma sahip olduğu görülmüştür. Evli olan bireylerin büyük çoğunluğunun büyük yaş grubunda ve lisans mezunu olabileceği göz önünde bulundurulduğunda, bu sonucun öğrenim durumu ve yaş değişkeni için elde edilen sonuçlarla uyumlu olduğu söylenebilir. Öğretmenlik mesleğine yönelik tutumu inceleyen çalışmalar incelendiğinde medeni durumun ele alındığı bir çalışma ile karşılaşılamamıştır.

Öğretmen adaylarının öğretmen öz-yeterlik algı puanlarının da medeni duruma göre anlamlı bir şekilde farklı olduğu ve evli olan öğretmen adaylarının daha yüksek öz-yeterlik puanına sahip olduğu görülmüştür. Evli bireylerin çocuk yetiştirme konusunda daha tecrübeli olacaklarından, okullardaki öğrencilerle başa çıkma konusunda ve onlara rehberlik etmede de 
kendilerini daha tecrübeli bulacaklarından, daha yeterli hissediyor olabilirler. Diğer bir ifade ile ailede öğretmenlik deneyimi kazanıyor olabilirler. Ancak Yaşar-Ekici (2017) araştırmasında bu çalışmanın sonucundan farklı olarak medeni durumun öğretmen öz-yeterliğini farklılaştırmadığını bulmuştur. Medeni durumun öğretmen öz-yeterlik algısı üzerindeki etkisinin küçük olması çalışma sonuçlarındaki farklılığın derin olmadığını göstermektedir.

Öğretmenlik mesleğini yapmayı ilk öncelikli görüp görmeme, hem mesleğe ilişkin tutumda hem de öğretmen öz-yeterlilik algısında önemli bir faktör olarak bulunmuştur. Böyle bir değişken oluşturulmasının nedeni, akademik derslerdeki karşılaşmalarda özellikle formasyon öğrencilerinin bu eğitimi aldıklarından pişman olduklarını, bu mesleği yapmayı istemediklerini veya başkalarının zoru ile formasyona, öğretmenliğe başvurduklarını belirtmeleridir. Öğretmenlik mesleğini yapmayı birincil öncelik olarak planlayan öğretmen adaylarının öğretmenliğe ilişkin tutumlarının anlamlı derecede daha olumlu olduğu, mesleğe ilişkin öz yeterlilik algılarının da anlamlı derecede daha yüksek olduğu bulunmuştur. Mesleği gelecekte yapmayı düşünen öğretmen adaylarının, mesleği sevdikleri, isteyerek bunu seçtikleri ve bu konuda kendilerini geliştirmek için yeterince motivasyona sahip oldukları düşünülebilir. Bu bağlamda elde edilen bulgular akla uygun görünmektedir.

Öğretmen adaylarının çalışma durumlarına göre öğretmenlik mesleğine yönelik tutum puanlarının farklılaştı̆̆ı, işçi olarak çalışan öğretmen adaylarının öğretmenlik mesleğine yönelik tutumlarının diğer tüm gruplardan anlamlı şekilde daha düşük olduğu bulunmuştur. Diğer araştırmalarda öğretmenlik tecrübesi olan öğretmen adaylarının mesleğe ilişkin daha olumlu tutuma sahip oldukları belirtilmektedir (Emam ve Mohamed, 2011). Bu durum mesleğe aşina olmanın önemli olabileceğini akla getirmektedir. Araştırmada yer alan meslek gruplarına bakıldığında işçi olarak çalışanların, memur ve ücretli öğretmenlere göre daha fazla fiziksel güç ile çalışan grup olduğu ve öğretmenlik mesleğine aşina olmalarının zor olduğu düşünülebilir. Bu nedenle zihinsel yoğunluğun ön plana çıktığı öğretmenliğe karşı daha olumsuz tutum benimsemiş olabilirler.

Öğretmen adaylarının çalışma durumlarına göre öğretmen öz-yeterlik algı puanlarının da farklılaştığı görülmüştür. Ücretli öğretmen olarak çalışan öğretmen adaylarının, işçi ve çalışmayanlara göre daha yüksek öz-yeterliğe algısına sahip oldukları bulunmuştur. Öğretmen sertifikası olmadan öğretmenlik yapan bu kişilerin, mesleği fiilen gerçekleştirdikleri için meslek yeterliklerine daha fazla sahip olmaları beklendik bir durum olarak ele alınabilir. Ayrıca mesleki uygulamalar konusunda tecrübe sahibi olanların olumlu tutuma sahip olmaları (Emam ve Mohamed, 2011), kendilerini meslekte yeterli görmelerini de sağlıyor olabilir. Gerçekçi algılar da bu durumun doğru bir yansıması olarak görülebilir. Çalışma durumu değişkenine ilişkin bir araştırmaya rastlanılmadığından bulguyu destekleyen veya karşı çıkan bir sonuç bulunamamıştır.

Öğretmen adaylarının öğretmenlik mesleğine yönelik tutumları ve öğretmen öz-yeterlik algıları gelir düzeylerine göre incelendiğinde MANOVA sonuçlarına göre bu iki değişken birlikte ele alındığında gruplar arası farklılık görülürken, farklılığın hangi değişken(ler)de olduğunu incelemek adına yapılan ANOVA da ise her iki değişken için de gruplar arası farklılık bulunmamıştır. Bu durumun sebebi MANOVA'daki küçük etki büyüklüğü ve değişkenlerin birlikte aynı yönde değişim göstermeleri ile açıklanabilir. Bağımlı değişkenler birlikte incelendiğinde ortaya çıkan küçük fark tek tek incelendiğinde daha da azalarak etkisiz hale 
gelmiştir. Öğretmen adaylarının gelir düzeylerinin değişmesi onların mesleğe bakış açılarını veya kendilerini mesleğe hazır hissetme düzeylerini değiştirmediği söylenebilir. Benzer şekilde Poyraz ve Çağırgan-Gülten (2014)'in çalışmasında da gelir düzeyinin öğretmenlik mesleğine yönelik tutumda önemli bir faktör olmadığı belirtilmektedir. Öğretmenlik mesleği çok geliri olan bir meslek olmadığından, bireylerin ekonomik durumları ile mesleğe ilişkin tutumda da önemli bir faktör olmayabileceği düşünülebilir.

Tutum, biraz zaman ve çaba istemekle birlikte değiştirilebilen bir özelliktir. Öğretmenlik mesleğinde verimli bir şekilde çalışmak için de oldukça önemli bir aktör olduğu ortaya çıkmıştır. Öğretmenlik mesleği öz yeterlilik algısı yüksek olan öğretmenlerin mesleki doyumlarının daha fazla olduğu ve öğrencilerinin de daha başarılı olduğu belirtilmektedir (Caprara, Barbaranelli, Steca ve Malone, 2006). Bu bağlamda mesleğe ilişkin olumsuz tutuma sahip olan BESYO öğrencileri ve öz-yetersizlik inancına sahip olan İlahiyat Fakültesi öğrencilerinin bu durumları daha fazla araştırılabilir. Meslekte daha fazla uygulama yapan adayların daha öz-yeterli hissetmeleri ve olumlu tutuma sahip olmaları, uygulamanın işlevine işarete etmektedir. Özellikle uygulamaya yönelik eğitim sürecinin mesleğe ilişkin tutum ve yeterlilik algısındaki etkisini belirlemek için boylamsal çalışmalar yapılabilir. Meslekte olan ögretmenlerinin tutum ve yeterlilik algıları ile meslekteki verimlilikleri incelenerek, öngörüde bulunulan kavramlar arasındaki ilişki araştırmalarla da ortaya konulabilir. Bu araştırma alana çok önemli bütüncül bir katkı sunmakla birlikte bazı sınırlılıklar da barındırmaktadır. Araştırmanın bulgularını genellerken sadece bir devlet üniversitesindeki öğrencilerden verilerin toplandığ dikkate alınmalıdır. 


\section{Kaynakça}

Abbasoğlu, E., ve Öncü, E. (2013). Beden eğitimi öğretmeni adaylarının benlik saygıları ve öğretmenlik mesleğine yönelik tutumları. Ahi Evran Üniversitesi Kırşehir Eğitim Fakültesi Dergisi, 14(2), 407-425.

Adıgüzel, A. (2017). The relationship between teacher candidates' pedagogical competence beliefs and their attitudes about teaching profession. Turkish Journal of Education, 6(3), 113-127.

Akça, F., Demir, S., ve Yılmaz, T. (2015). Öğretmen adaylarının özyeterlik algıları ile akademik kontrol odaklarının karşılaştıılması, Journal of Innovative Human Sciences. http://sproc.org/ojs/index.php/IJIRE, 2(1),01-09

Baloğlu, N., ve Karadağ, E. (2008). Öğretmen yetkinliğinin tarihsel gelişimi ve Ohio öğretmen yetkinlik ölçeği: Türk kültürüne uyarlama, dil geçerliği ve faktör yapısının incelenmesi. Kuram ve Uygulamada Eğitim Yönetimi, 56(56), 571-606.

Bandura, A. (1997). Self-efficacy: The exercise of control. New York: Freeman.

Bümen, N. T., ve Özaydın, T. E. (2013). Adaylıktan göreve öğretmen özyeterliği ve öğretmenlik mesleğine yönelik tutumlardaki değişimler. Eğitim ve Bilim, 38(169), 109-125.

Can, Ş. (2017). Pedagojik formasyon programı öğrencilerinin öğretmenlik mesleğine yönelik düşünceleri. Ahi Evran Üniversitesi Kırşehir Eğitim Fakültesi Dergisi (KEFAD), 18(1), 595-611.

Caprara, G. V., Barbaranelli, C., Steca, P.ve Malone, P. S. (2006). Teachers' self-efficacy beliefs as determinants of job satisfaction and students' academic achievement: A study at the school level. Journal of school psychology, 44(6), 473-490.

Cebeci Emre, Ş. ve Ünsal, S. (2017). The investigation of the relationship between secondary school teachers' self efficacy beliefs and attitude towards teaching. European Journal of Education Studies, 3(6), 94.-111.

Cüceloğlu, D. (2006). Insan ve davranışı. İstanbul: Remzi.

Çapa, Y., ve Çil, N. (2000). Öğretmen adaylarının öğretmenlik mesleğine yönelik tutumlarının farklı değişkenler açısından incelenmesi. Hacettepe Üniversitesi Eğitim Fakültesi Dergisi, 18, 69-73.

Çapa, Y., Çakıroğlu, J., ve Sarıkaya, H. (2005). Öğretmen özyeterlik ölçeği Türkçe uyarlamasının geçerlik ve güvenirlik çalışması. Eğitim ve Bilim, 30(137), 74-81.

Çetin, O. (2017). An investigation of pre-service science teachers' level of efficacy in the undergraduate science teacher education program and pedagogical formation program. Journal of Education and Practice, 8(12), 22-32.

Dadand, İ., Kalyon, A., ve Yazıc1, H. (2016). Eğitim fakültesinde öğrenim gören ve pedagojik formasyon eğitimi alan öğretmen adaylarının öz-yeterlik inançları, kaygı düzeyleri ve öğretmenlik mesleğine karşı tutumları. Bayburt Eğitim Fakültesi Dergisi, 11(1), 253-269.

Demirtaş, H., Cömert, M., ve Özer, N. (2011). Öğretmen adaylarının özyeterlik inançları ve öğretmenlik mesleğine ilişkin tutumları. Eğitim ve Bilim, 36(159), 96-111.

Elkatmış, M., Demirbaş, M., ve Ertuğrul, N. (2013). Eğitim fakültesi öğrencileri ile formasyon eğitimi alan fen edebiyat fakültesi öğrencilerinin öğretmenlik mesleğine yönelik öz yeterlik inançları. Pegem Ĕ̈itim ve Öğretim Dergisi, 3(3), 41-50.

Emam, M. M., ve Mohamed, A. H. H. (2011). Preschool and primary school teachers' attitudes towards inclusive education in Egypt: The role of experience and self-efficacy. Procedia-Social and Behavioral Sciences, 29, 976-985.

Erdamar, G., Aytaç, T., Türk, N., ve Arseven, Z. (2016). The effects of gender on attitudes of preservice teachers towards the teaching profession: a meta-analysis study. Universal Journal of Educational Research, 4(2), 445-456.

Güngör, S., ve Özdemir, Y. (2017). Perceived teacher self-efficacy of teacher candidates enrolled in the pedagogical formation certificate program. International Journal of Higher Education, 6(6), 112 
Gürbüz, H. ve Kışoğlu, M. (2007). Tezsiz yüksek lisans programına devam eden fen edebiyat ve eğitim fakültesi öğrencilerinin öğretmenlik mesleğine yönelik tutumları (Atatürk Üniversitesi Örneği). Erzincan Eğitim Fakültesi Dergisi, 9(2), 71-83.

Ilgaz, G., Bülbül, T., ve Çuhadar, C. (2013). Öğretmen adaylarının eğitim inançları ile öz-yeterlik algıları arasındaki ilişkinin incelenmesi. Abant İzzet Baysal Üniversitesi Eğitim Fakültesi Dergisi, 13(1), $50-65$.

İpek, C. ve Demirel, İ. N. (2012). Sınıf öğretmenliği ve pedagojik formasyon programı öğretmen adaylarının öğretmen özyeterlik inançları. Bayburt Üniversitesi Eğitim Fakültesi Dergisi, 7(1), 54-67.

Kağıtçıbaşı, Ç. (2013). Günümüzde insan ve insanlar. İstanbul: Evrim.

Kaya. M. (2003). Ondokuz Mayıs Üniversitesi İlahiyat Fakültesi son sınıf öğretmen adaylarının öğretmenlik uygulaması ile öğretmenlik mesleğine yönelik tutumları arasındaki ilişkinin incelenmesi. Ondokuz Mayls Üniversitesi İlahiyat Fakültesi Dergisi, 14(14-15), 89-115.

Kenrick, D. T., Neuberg, S. T. \& Cialdini, R. B. (2005). Social psychology: Unraveling the mystery (3th edition). Boston, MA: Pearson.

Loreman, T., Sharma, U.,ve Forlin, C. (2013). Do Pre-service teachers feel ready to teach in inclusive classrooms? A four country study of teaching self-efficacy. Australian Journal of Teacher Education, 38(1), 27- 44.

Milli Eğitim Bakanlığı. (2017). Öğretmenlik Mesleği Genel Yeterlikleri. Ankara.

Ömür, Y. E., ve Nartgün, Ş. S. (2013). Öğretmen adaylarının öğretmenlik mesleğine ilişkin tutumları ile güdülenme düzeyleri arasındaki ilişsi. Eğitimde Politika Analizi Dergisi, 2(2), 41-55.

Özkan, H. H. (2012). Öğretmenlik formasyon programındaki öğretmen adaylarının öğretmenlik mesleğine ilişkin tutumlarının incelenmesi (SDU Örneği). Ahi Evran Üniversitesi Kırşsehir Eğitim Fakültesi Dergisi (KEFAD), 13(2), 29-48.

Polat, S. (2013). Pedagojik formasyon sertifika programı ve eğitim fakültesi öğrencilerinin öğretmenlik mesleğine yönelik tutumlarının incelenmesi. e-Uluslararası Eğitim Araştırmaları Dergisi, 4 (2), 1389-1404.

Poyraz, C., Çağırgan Gülten, D. (2014). Pre-service mathematics teachers' attitudes towards the profession of teaching. International Online Journal of Educational Sciences, 6(3), 107-114.

Richardson, V. (1996). In J. Sikula (Ed.). Handbook of research on teacher education (second edition, pp. 102-119). New York: Macmillan

Rimm-Kaufman, S. E., \& Sawyer, B. E. (2004). Primary-grade teachers' self-efficacy beliefs, attitudes toward teaching, and discipline and teaching practice priorities in relation to the" responsive classroom" approach. The Elementary School Journal, 104(4), 321-341.

Recepoğlu, E. (2013). Öğretmen adaylarının yaşam doyumları ile öğretmenlik mesleğine ilişkin tutumları arasındaki ilişkinin incelenmesi. Hacettepe Üniversitesi Eğitim Fakültesi Dergisi(1), 311-326.

Sandıkçı, M., ve Öncü, E. (2013). Beden eğitimi ile diğer alanlardaki öğretmen adaylarının öğretmenlik mesleğine ilişkin yeterlik algıları ve tutumlarının belirlenmesi ve karşılaştırılması. Pamukkale Journal of Sport Sciences, 4(1), 135-151.

Savolainen, H., Engelbrecht, P., Nel, M., ve Malinen, O. P. (2012). Understanding teachers' attitudes and self-efficacy in inclusive education: Implications for pre-service and in-service teacher education. European Journal of Special Needs Education, 27(1), 51-68.

Serin, M. K., Güneş, A. M., ve Değirmenci, H. (2015). Sınıf öğretmenliği bölümü öğrencilerinin öğretmenlik mesleğine yönelik tutumları ile mesleğe yönelik kaygı düzeyleri arasındaki ilişki. Cumhuriyet Uluslararası Eğitim Dergisi, 4(1), 21-34.

Stevens, J.P. (2009). Applied Multivariate Statistics for the Social Sciences.(5th ed).USA:Routledge, Taylor and Francis Group.

Tabachnick, B.G. \& Fidell, L.S.(2006). Using multivariate statistics.(5th ed). USA:Pearson Education, Inc 
Tschannen-Moran, M. \& Woolfolk-Hoy, A. (2001). Teacher efficacy: Capturing an elusive construct. Teaching and Teacher Education, 17, 783-805.

Tschannen-Moran, M., Hoy, A. W. \& Hoy, W. K. (1998). Teacher efficacy: Its meaning and measure. Review of Educational Research, 68 (2), 202-248.

Ünsal, S., Korkmaz, F., ve Perçin, S. (2016). Analysis of mathematics teachers' self-efficacy levels concerning the teaching process. Journal of Education and Practice, 7(24), 99-107.

Üstüner, M. (2006). Öğretmenlik mesleğine yönelik tutum ölçeğinin geçerlik ve güvenirlik çalışması. Kuram ve Uygulamada Eğitim Yönetimi, 45(45), 109-127.

Yaşar Ekici, F. (2017). Okul öncesi öğretmen adayları ile pedagojik formasyon eğitimi alan öğretmen adaylarının öğretmenliğe yönelik özyeterlik inançlarının karşılaştırılması. Insan ve Toplum Bilimleri Araştırmalart Dergisi-Journal of the Human and Social Science Researches, 6(5), 3003-3022.

Yüksel, S. (2004). Tezsiz yüksek lisans programının öğrencilerin öğretmenlik mesleğine ilişkin tutumlarına etkisi. Uludağ Üniversitesi Eğitim Fakültesi, XVII (2), 355-379. 


\section{Extended Abstract}

\section{Introduction}

"What are the qualifications that a good teacher should have?" very different answers may be told to this question. Nevertheless, teachers' positive attitude towards their profession and the positive perception of profession self-efficacy can be seen as two important features. As a matter of fact, it is stated that these two features are important structures in terms of the teacher's intellectual processes, classroom practices, change and learning for teaching. (Richardson, 1996; Rimm-Kaufman and Sawyer, 2004). Knowing how much teachers have these qualifications will also give a clue as to how well they are teachers.

Teacher self-efficacy is the teachers' judgment about they have the ability to make students to succeed and learn (Armor et al., 1976, Bandura, 1977, cited in: Tschannen-Moran and Woolfolk-Hoy, 2001). According to this, a teacher candidate's perception of how successful he will be in this profession when he starts to his profession constitutes his self-efficacy belief. (Ipek and Demirel, 2012). In addition to this, attitudes are a determinant of the individuals' behaviors. Thus, it is obvious that pre-service teachers' attitudes towards the profession will provide information to predict the performance they will perform when they start teaching profession (Üstüner, 2006). As a conclusion, it has been observed that pre-service teachers' selfefficacy beliefs and their attitudes towards the profession have important effects on the successful performance of the teaching profession (Demirtaş, Cömert and Özer, 2011).

Although, education faculties of universities have played a leading role in teacher training, other faculties such as Theology, School of Physical Education and Sports and teacher certificate programs are also among teacher-training resources in Turkey. With the diversification of teacher training resources, the extent to which teachers can acquire the qualifications required of teachers has been the subject of discussion (Yüksel, 2004). Also, which faculty students have more positive attitudes or teacher self-efficacy beliefs have been compared. When the researches about the subject are examined, it is seen that only the binary comparisons of the sources were made. In this study, students from all teaching training sources were reached. In this way, preservice teachers' attitudes towards teaching profession and teacher self-efficacy beliefs were examined and compared in terms of all teacher training units.

The aim of this study was to examine the attitudes towards teaching profession and the self-efficacy beliefs of preservice teacher who are attending the Faculty of Education (EF), Faculty of Theology (TF), School of Physical Education and Sports (SPES), Faculty of Science and Letters (SLF) and Pedagogical Formation Education (PFE). In addition, self-efficacy beliefs and attitudes towards the profession of the pre-service teachers were examined in terms of different variables such as age, gender, marital status, prioritization of being teacher, educational status, working status and income level.

\section{Method}

In the study, relational screening model among the quantitative research methods was chosen as a research design. Sample was consisting of 786 students from EF, TF, SPES, SLF and PFE in a public university in Turkey. Care was taken to ensure that the undergraduate students in the study group were in junior or senior year in order to they could recognize the teaching well. 
For data collection, attitudes towards teaching profession scale which developed by Çetin (2006) and teaching self-efficacy scale which developed by Tschannen-Moran and Woolfolk-Hoy and adapted to Turkish by Baloğlu and Karadağ (2008) were used. Both scales have three dimensions. Reliability of scales was calculated .94 and .90 , for attitudes towards teaching profession and teaching self-efficacy beliefs scale, respectively.

In analysis, multivariate analysis of variance (MANOVA) was used, in order to decrease risk of type I error. That is because it is mentioned that dependent variables, attitudes towards teaching profession and teaching self-efficacy beliefs are related to each other in literature.

\section{Results and Discussion}

According to the results of the study, a moderate positive relationship was found between the attitudes towards teaching profession and teaching self-efficacy beliefs. Demirtaş, Cömert and Özer (2011) and Dadand1, Kalyon and Yazıc1 (2016) also found a significant positive correlation between the two variables. The findings show that these two variables are related.

All MANOVA results of the study were significant. This result indicates that the attitudes towards teaching profession and teachers' self-efficacy beliefs change together. In addition, all independent variables used in the research were effective on dependent variables. In particular, faculty and gender variables that have moderate effects on dependent variables, and the variable of prioritization of being teacher have large effect size can be expressed as the most effective variables in the study.

When the attitudes of the preservice teachers towards the teaching profession were examined in terms of faculties, it was found that the preservice teachers, studying at SPES were more negative attitudes than the other student groups but there is no significant difference between the other faculty students. When focused on teacher self-efficacy beliefs, it was found that pre-service teachers that studying at TF was more negative than all other student groups, but there was no significant difference between the other faculty students.

It was observed that female teacher candidates' attitudes towards teaching profession were significantly higher than male. It can be said that this result is similar to the results obtained from the other studies. But there was no significant difference in teaching self-efficacy beliefs in term of gender. It was found that the preservice teachers who plan being teacher as a primary priority have significantly more positive attitudes towards teaching and self-efficacy beliefs. There were significantly differences both attitudes towards teaching and teacher selfefficacy beliefs in terms of age, marital status, graduation status, working status and income levels. 